\title{
Bat-infesting chiggers (Acariformes: Trombiculidae) of the Balearic Islands and new data on the genus Trisetica Traub et Evans, 1950
}

\author{
Alexandr A. Stekolnikov ${ }^{1}$ and Juan Quetglas ${ }^{2}$ \\ ${ }^{1}$ Zoological Institute of the Russian Academy of Sciences, Saint Petersburg, Russia; \\ ${ }^{2}$ Murciélagos y más, Espartinas, Spain
}

\begin{abstract}
A sample of chigger mites from bat hosts collected in the Balearic Islands (Western Mediterranean Sea) is found to include two species. These are the first records of bat-infesting chiggers identified to species in Spain. Chiggers collected from Pipistrellus kuhlii (Kuhl) in Menorca are identified as Oudemansidium komareki (Daniel et Dusbábek, 1959); this species, which was known from Austria, Bulgaria, Romania, Slovakia, Moldova, Crimea, and Azerbaijan, is recorded for the first time in Spain. Chiggers collected from Plecotus austriacus (Fischer) in Formentera are identified as Trombicula knighti Radford, 1954, which was insufficiently described from a bat in Yemen and known only from its type locality. We transfer this species to the genus Trisetica Traub et Evans, 1950 and provide its re-description based on paratypes and the material from the Balearic Islands. The species Sasatrombicula (Rudnicula) balcanica Kolebinova, 1966 is synonymised with T. knighti. One species closely related to T. knighti, Trisetica aethiopica (Hirst, 1926), which was recorded in Ghana, Uganda, South Sudan, and Madagascar, is re-described on the basis of its syntype deposited in the Natural History Museum, London, UK. This specimen is designated as lectotype.
\end{abstract}

Keywords: Chigger mites, Mediterranean, Spain, Africa, bat hosts, Pipistrellus kuhlii, Plecotus austriacus

The trombiculids is a large group of temporary parasites of terrestrial vertebrates comprising, according to some estimations (Fernandes and Kulkarni 2003), more than 3,000 species, most of which are known only from the parasitic larval stage. In Spain, 20 chigger species are known, including some having medical and veterinary importance (Stekolnikov et al. 2014, 2016). Although trombiculids are not species-specific, as might be expected for temporary parasites, the fact that some chigger species and genera have preferences for classes or orders of hosts with different natural histories and mode of activity are well known. Thus, bats have a highly specific chigger fauna comprising many genera (Kudryashova 1998, Stekolnikov 2018). Since no collections of chiggers from bat hosts were made previously in Spain, our material from two species of Chiroptera caught in the Balearic Islands provides the first data on the fauna of bat-infesting trombiculids in the country.

One of the chigger species found in our material, Oudemansidium komareki (Daniel et Dusbábek, 1959), is a common parasite of bats in Europe, but has not been recorded in Spain. The identification of the second species was much more difficult. We identified it as a species of the genus Trisetica Traub et Evans, 1950, similar to Trisetica aethiopica (Hirst, 1926). Then examination of the litera- ture data on the chigger genera close to Trisetica led us to the supposition that this species could be identical to an insufficiently described species Trombicula knighti Radford, 1954. Fortunately, we had a possibility to examine type specimens of the above two species in the collections of the Natural History Museum (NHM, London, UK) and Zoological Institute of the Russian Academy of Sciences (ZIN, Saint Petersburg, Russia).

The species T. aethiopica is represented in NHM by a single specimen; its examination allowed us to complement the brief original description of this species. The specimen is designated here as lectotype. We also examined paratypes of T. knighti in NHM and ZIN that confirmed the attribution of the specimens from Spain to this species. The full re-description of this species is based on the examination of both type and additional materials.

\section{MATERIALS AND METHODS}

New mites from Balearic Islands were collected by J. Quetglas in two different expeditions. In 2004 at Formentera Island, just a single sample of ectoparasites was taken as extra material while working on an inventory of bat species. The finding of a dead long-eared bat, Plecotus austriacus (Fisher), allowed the collection of chiggers with some bat skin, avoiding the use of tweezers,

Address for correspondence: A.A. Stekolnikov, Zoological Institute of the Russian Academy of Sciences, Universitetskaya Embankment 1, Saint Petersburg 199034, Russia. Phone +7 812328 0711; Fax: +7 812328 2941; E-mail: Alexandr.Stekolnikov@zin.ru 


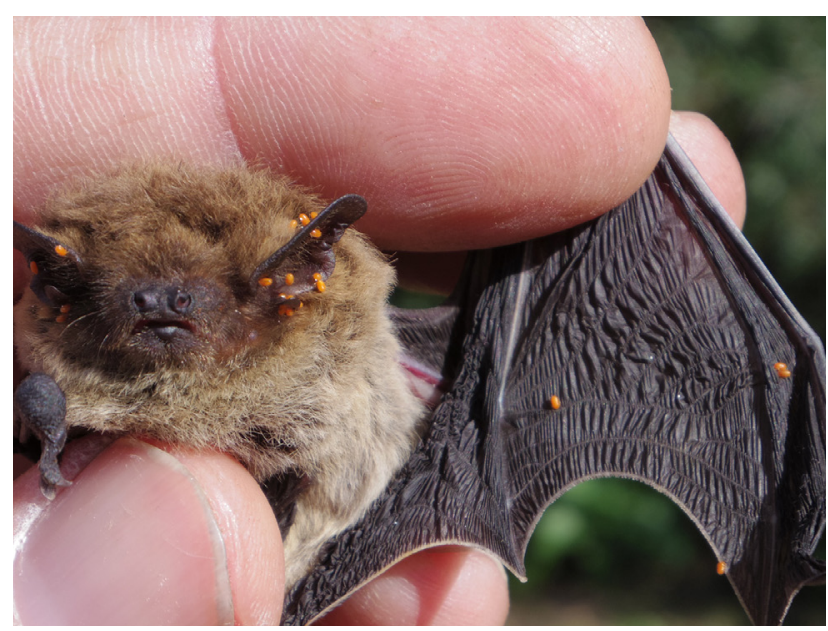

Fig. 1. Larvae of Oudemansidium komareki (Daniel et Dusbábek, 1959) on Pipistrellus kuhlii (Kuhl) (photographed by Juan Quetglas).

which usually damages the larvae before they are released from the bat.

In 2017-2018, a survey of bat-boxes was taken in Menorca Island on a season-based schedule. One visit per season plus an extra winter visit one year later lead to the handling of 50 bats of two species of the non-troglophilic genus Pipistrellus Kaup, which were checked for the presence of ectoparasites. Twenty-six Pipistrellus kuhlii were checked in two winters (12 on 12-13 January 2018 and 14 on 26 December 2018), seven in spring (23-24 April 2017), three in summer (13 July 2017) and 13 in autumn (31 October and 1 November 2017); one specimen of Pipistrellus pipistrellus (Schreber) was also checked during the last period. Only one individual was found to be parasitised by chiggers ( $P$. kuhlii, 12 January 2018). About 30-40 very conspicuous, bright orange engorged larvae were attached to the ears and to all parts of the wing membrane (propatagium, plagiopatagium, dactylopatagium and uropatagium) (Fig. 1). The bat was wintering in a bat-box with two other uninfested $P$. kuhlii. Chiggers were removed using O'TOM tick twisters (H3D, Lavancia, France) and stored in Eppendorf tubes with $70 \%$ ethanol at room temperature.

Preparation and identification of the new material was done in the Laboratory of Parasitic Arthropods, Zoological Institute of the Russian Academy of Sciences (ZIN, Saint Petersburg, Russia). Mites were mounted on glass slides using de Faure's medium. Slides were examined under a Leica DM5000B microscope (Leica Microsystems GmbH, Wetzlar, Germany) using differential interference contrast. Microphotographs were taken with the use of a ToupCam 5.1 digital camera, model FMA050 (Hangzhou ToupTek Photonics Co., Ltd., Hangzhou, Zhejiang, China). Measurements and drawings were made using a microscope MBI-3 (LOMO plc, St. Petersburg, Russia) supplied with phase contrast optics. Measurements (in micrometres) were taken with an ocular micrometre; drawings were prepared using a camera lucida.

A syntype of Trisetica aethiopica and two paratypes of Trombicula knighti were examined by A. Stekolnikov during his visit to NHM in November 2017. The arrangement of the idiosomal setae was drawn using an Olympus BH-2 microscope (Olympus Corporation, Tokyo, Japan) with a drawing tube; measurements were performed using a Zeiss Axiophot microscope (Carl Zeiss AG, Oberkochen, Germany) with an ocular micrometre. A micro- photograph of T. aethiopica was made using an Olympus BX61 microscope equipped with an Olympus DP73 digital camera.

In the schemes of the dorsal idiosomal setae arrangement (Figs 2A, 10A), tentative bounds between rows of setae are outlined by dotted lines. The double circles in the figures of the legs (Fig. 8) represent the bases of unspecialised tactile setae; single circles correspond to the unspecialised setae situated on the opposite side of the leg.

\section{RESULTS}

Genus Trisetica Traub et Evans, 1950

Trisetica - Traub and Evans (1950): 356.

Trisetica - Vercammen-Grandjean (1965): 132; (1967):

849; (1968): 109; Stekolnikov (2018): 116.

Type species: Trisetica melvini Traub et Evans, 1950, by original designation.

Species included: Trisetica melvini, Trisetica aethiopica, Trisetica knighti comb. $\mathrm{n}$.

$\mathrm{D}$ i a g n o s i s : SIF $=4$ (5 in T. melvini) B-N(b)-3-(2-3)111.0000; $\mathrm{fsp}=7.7 .7 ; \mathrm{fSt}=2.2(6$ in T. melvini $) ; \mathrm{fCx}=1.1 .1 ; \mathrm{Ip}=730$ 952. Cheliceral blade with tricuspid cap; galeal setae nude (in $T$. knighti sometimes with small cilium); palpal claw 3-pronged; palpal tarsus with 4 branched setae (5 in T. melvini). Scutum with reduced posterior angles (peniscutum), with $1 \mathrm{AM}, 2 \mathrm{AL}$ setae and fusiform or slightly expanded sensilla covered with setules; 2 PL setae extrascutal. Eyes $2+2$. Legs 7-segmented, 3 genualae I ( 2 in T. melvini), 1 genuala II, tibiala and genuala III present, mastisetae absent, all leg coxae unisetose.

\section{Trisetica knighti (Radford, 1954) comb. n.}

Trombicula knighti - Radford (1954): 298, fig. 49;

Kolebinova (1966): 74, figs 1-5.

Trombicula (Anomalaspis) knighti

- Vercammen-Grandjean and Nadchatram (1963): 385.

Sasatrombicula (Rudnicula) knighti

- Vercammen-Grandjean (1965): 68.

Rudnicula knighti - Brown et al. (1988): 17.

Sasatrombicula (Rudnicula) balcanica

- Kolebinova (1966): 74, figs 6-11, syn. n.;

Kolebinova (1992): 69, fig. 36.

Rudnicula balcanica - Brown et al. (1988): 17.

Holotype dep osition: National Museum of Natural History, Washington, DC, USA (Radford 1954, Goff 1989).

D i a g n o s i s: SIF = 4B-N(b)-3(4)-3111.0000; fsp = 7.7.7; fCx $=1.1 .1 ; \mathrm{fSt}=2.2 ; \mathrm{fPp}=\mathrm{B} / \mathrm{B} / \mathrm{NNB} ; \mathrm{fSc}: \mathrm{AM} \geq \mathrm{PL}>\mathrm{AL} ; \mathrm{Ip}=$ 817-952; fD = 2H-10-14(15)-9(11)-8(7)+(5-11); DS = 47-54; $\mathrm{VS}=48-62 ; \mathrm{NDV}=102-109$. Standard measurements are given in Table 1. The re-description is based on one paratype from ZIN, one paratype from NHM (1952.7.23.9), and five additional specimens (ZIN 11168-11172).

Re-description ( larva) 


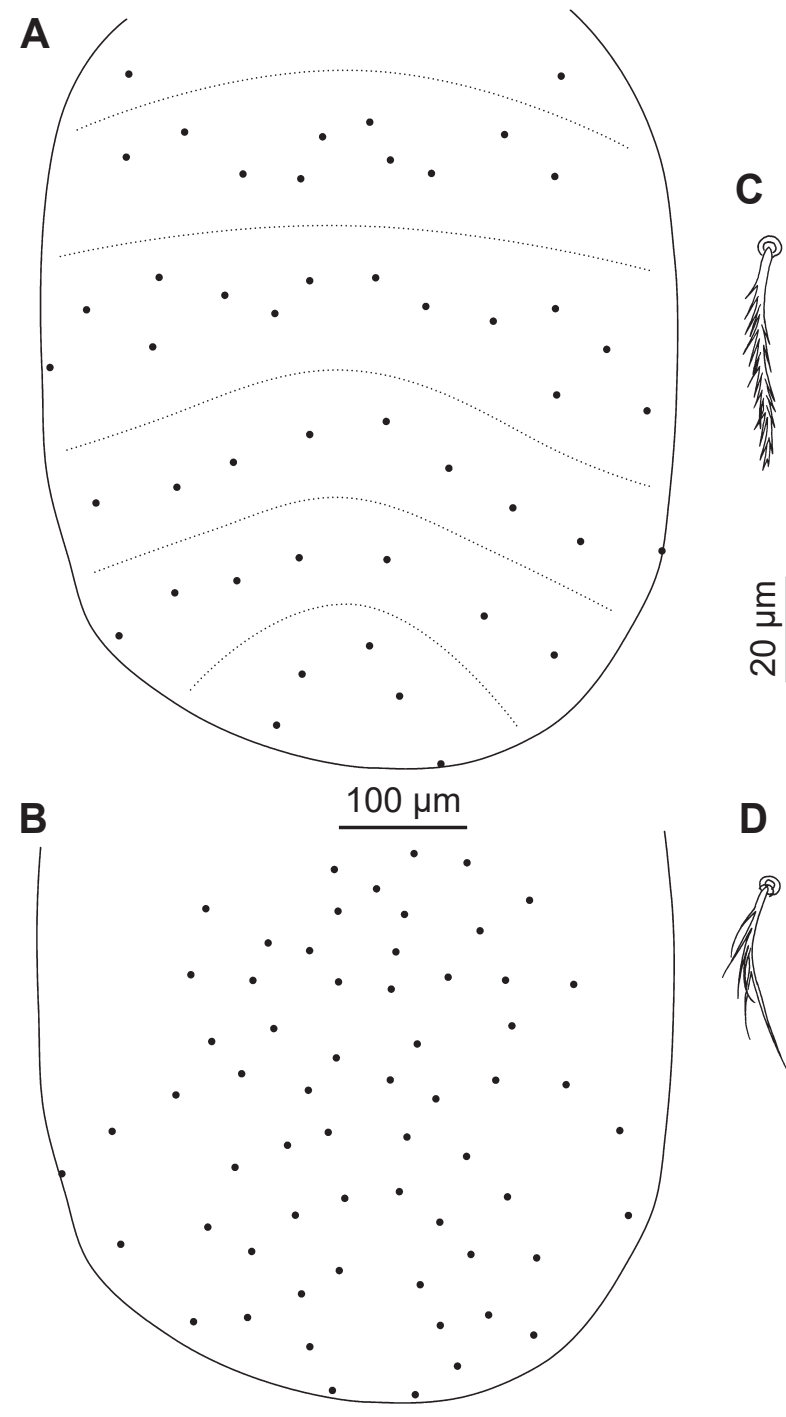

Fig. 2. Trisetica knighti (Radford, 1954), larva. A - arrangement of dorsal idiosomal setae in a paratype (ZIN); B - arrangement of ventral idiosomal setae in a paratype (ZIN; excretory pore is invisible); C - dorsal idiosomal seta in specimen ZIN 11168; D - ventral preanal idiosomal seta in specimen ZIN 11168. Scale bar $100 \mu \mathrm{m}$ (A, B), $20 \mu \mathrm{m}(\mathrm{C}, \mathrm{D})$.

\section{Idiosoma}

Figs 2-4

Eyes $2+2$. One pair of humeral setae and 45-52 barbed dorsal idiosomal setae; always 10 setae in $1^{\text {st }}$ row, 14 (15 in one additional specimen) setae in $2^{\text {nd }}$ row, 11 (in two additional specimens) or 9 (in one paratype and two additional specimens) setae in $3^{\text {rd }}$ row, 8 (in two additional specimens) or 7 (in one paratype and two additional specimens) setae in $4^{\text {th }}$ row, next 5-11 setae with ambiguous distribution by rows; four sternal setae; 48-62 ventral setae; total number of idiosomal setae (NDV), excluding coxal and sternal, 102-109.

\section{Gnathosoma}

Fig. 5

Cheliceral blade with tricuspid cap; gnathobase sparsely covered with rather large puncta and bears one pair of

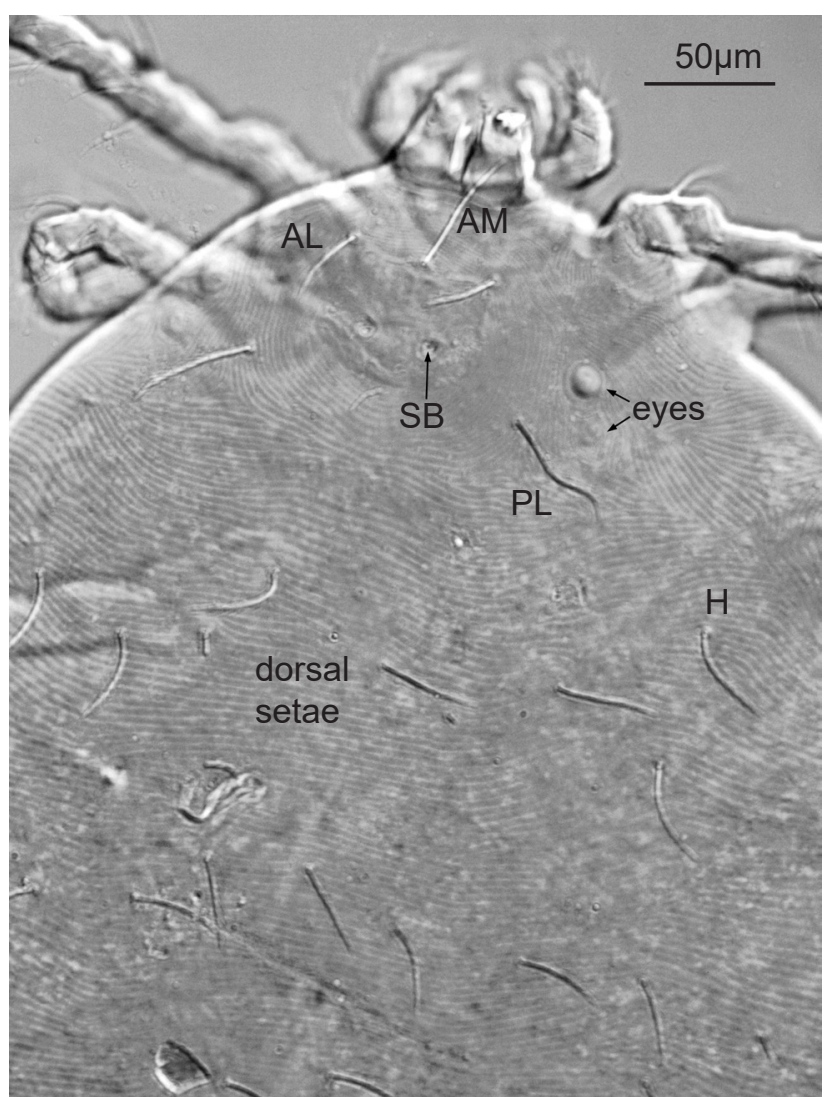

Fig. 3. Trisetica knighti (Radford, 1954), larval specimen ZIN 11170: scutum and dorsal idiosomal setae (sensilla missing). $A b$ breviations: AL - anterolateral scutal seta; AM - anteromedian scutal seta; $\mathrm{H}$ - humeral seta; PL - posterolateral scutal seta; SB - sensillary base.

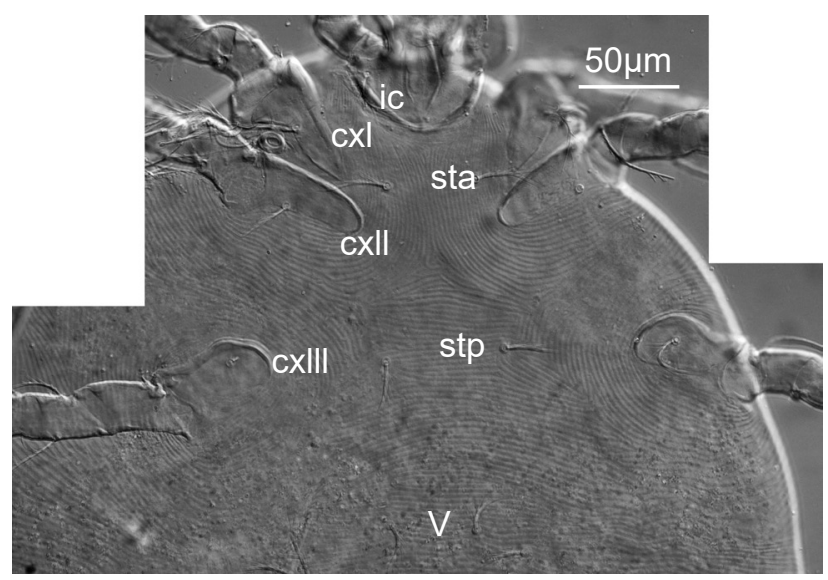

Fig. 4. Trisetica knighti, larval specimen ZIN 11170: sternal area of idiosoma. Abbreviations: cxI - coxa I; cxII - coxa 2; cxIII coxa III; ic - infracapitulum (gnathobase); sta - anterior sternal seta; stp - posterior sternal seta; V - ventral preanal setae.

branched setae; galeal setae nude or having small cilium (in specimen ZIN 11169); palpal claw with 3 visible prongs (4 prongs in specimen ZIN 11168); palpal femoral and genual setae with long branches, dorsal and lateral palpal tibial setae nude, ventral palpal tibial seta branched; palpal tarsus with 4 branched setae and basal tarsala. 
A

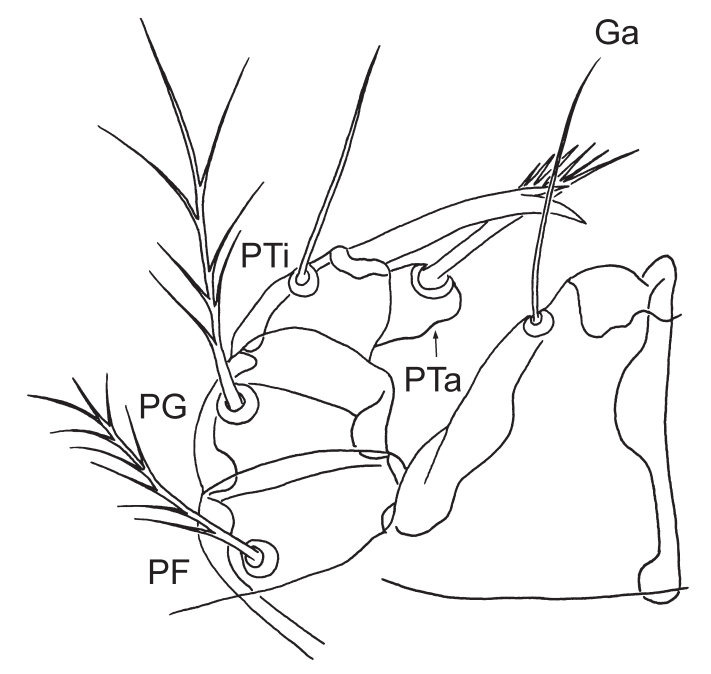

C

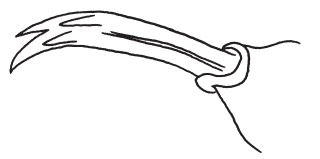

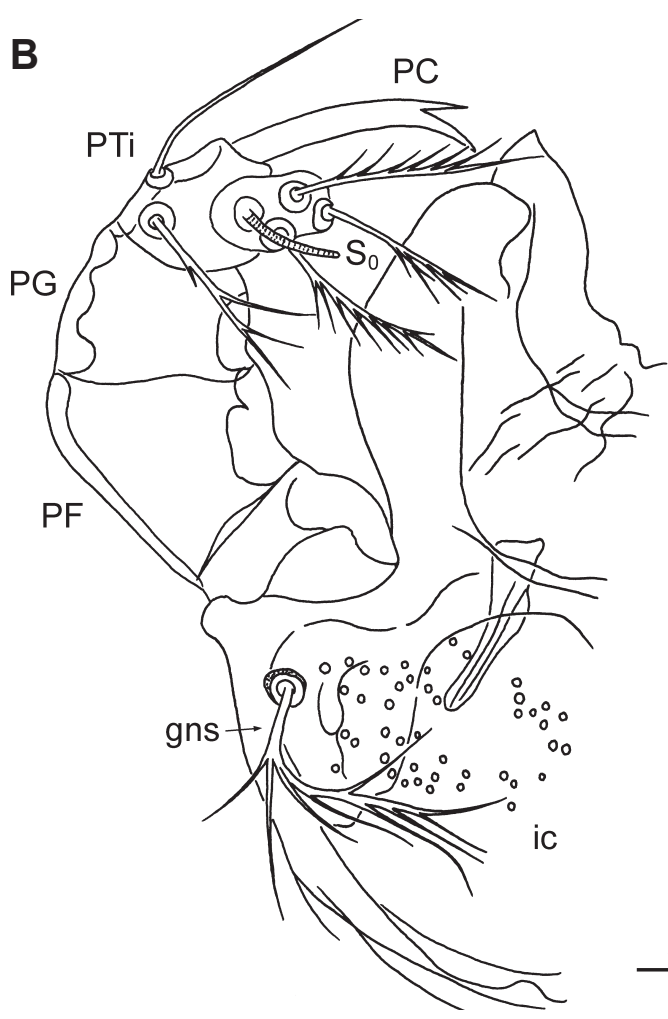

$20 \mu \mathrm{m}$

Fig 5. Trisetica knighti (Radford, 1954), larval specimen ZIN 11168. A - dorsal aspect of gnathosoma (cheliceral blade missing, only two prongs of palpal claw are visible); B - ventral aspect of gnathosoma (cheliceral blade missing, only two prongs of palpal claw are visible); C - palpal claw. Abbreviations: Ga - galeal seta; gns - gnathocoxal seta; ic - infracapitulum (gnathobase); PC - palpal claw; $\mathrm{PF}$ - palpal femur; PG - palpal genu; PTa - palpal tarsus; PTi - palpal tibia; $\mathrm{S}_{0}$ - palpal tarsala.

Table 1. Trisetica knighti (Radford, 1954): measurements (in $\mu \mathrm{m}$ ) and counts.

\begin{tabular}{lccccc}
\hline & Paratype (ZIN) & $\begin{array}{c}\text { Paratype } \\
(\mathrm{NHM})\end{array}$ & $\begin{array}{c}\text { Specimens } \\
\text { Range }\end{array}$ & $\begin{array}{c}\text { Balearic Islands }(\mathrm{n}=4) \\
\text { Mean }\end{array}$ & $\begin{array}{c}\text { Sasatrombicula (Rudnicula) } \\
\text { balcanica* }\end{array}$ \\
\hline $\mathrm{AW}$ & 51 & 47 & $51-58$ & 55 & $47-65$ \\
$\mathrm{SB}$ & 23 & 21 & $24-25$ & 24 & $21-25$ \\
$\mathrm{ASB}$ & 32 & 33 & $32-35$ & 34 & $30-31$ \\
$\mathrm{PSB}$ & 20 & - & $18-23$ & 20 & $47-48$ \\
$\mathrm{SD}$ & 52 & - & $52-57$ & 54 & $29\left(39^{* *}\right)$ \\
$\mathrm{AM}$ & 48 & 38 & $50-51$ & 51 & $35-44$ \\
$\mathrm{AL}$ & 35 & 34 & $31-40$ & 35 & $46-47$ \\
$\mathrm{PL}$ & 50 & 52 & $46-51$ & 49 & $40-55$ \\
$\mathrm{H}$ & 41 & 45 & $40-45$ & 43 & $34-35$ \\
$\mathrm{D}_{\text {min }}$ & - & 30 & $26-31$ & 30 & $26-28$ \\
$\mathrm{D}_{\text {max }}$ & 38 & 39 & $38-40$ & 39 & $27-32$ \\
$\mathrm{~V}_{\text {min }}$ & - & - & $23-27$ & 24 & $286-295$ \\
$\mathrm{~V}_{\text {max }}$ & - & - & $32-35$ & 34 & $242-254$ \\
pa & 290 & 299 & $319-335$ & 328 & $269-274$ \\
pm & 243 & 256 & $275-284$ & 280 & $809-811$ \\
pp & 284 & 296 & $324-338$ & 332 & 50 \\
$\mathrm{Ip}$ & 817 & 851 & $918-952$ & 940 & 50 \\
$\mathrm{DS}$ & 47 & - & $52-54$ & 53 & $82-100$ \\
VS & 62 & - & $48-55$ & 53 & $78^{* *}$ \\
NDV & 109 & - & $102-109$ & 106 & -
\end{tabular}

Abbreviations: AW - distance between anterolateral scutal setae; SB - distance between sensillary bases; ASB - distance from the level of sensillary bases to extreme anterior margin of scutum; PSB - distance from the level of sensillary bases to extreme posterior margin of scutum; SD - length of scutum (ASB + PSB); AM - length of anteromedian scutal seta; AL - length of anterolateral scutal setae; PL - length of posterolateral scutal setae; $\mathrm{H}$ - length of humeral setae; $\mathrm{D}_{\min }$ - length of the shortest dorsal idiosomal seta; $\mathrm{D}_{\max }-$ length of the longest dorsal idiosomal seta; $\mathrm{V}_{\min }$ - length of the shortest ventral idiosomal seta; $\mathrm{V}_{\text {max }}$ - length of the longest ventral idiosomal seta; pa - length of leg I (including coxa); pm length of leg II (including coxa); pp - length of leg III (including coxa); Ip - sum of leg lengths (pa + pm + pp); DS - number of dorsal idiosomal setae (including humeral); VS - number of ventral idiosomal setae (excluding coxal and sternal); NDV - number of idiosomal setae (DS + VS); TaIIIL - length of leg tarsus III; TaIIIW - width of leg tarsus III. 


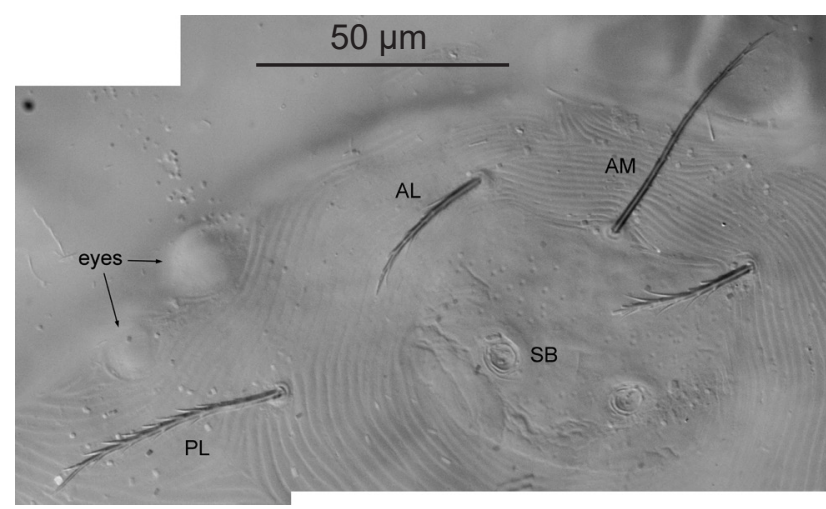

Fig. 6. Trisetica knighti (Radford, 1954), larval specimen ZIN 11170: scutum (sensilla missing). Abbreviations: AL - anterolateral scutal seta; AM - anteromedian scutal seta; PL - posterolateral scutal seta; $\mathrm{SB}$ - sensillary base.

\section{Scutum}

Figs 3, 6, 7

Nearly hexagonal, with broadly rounded posterior margin and sparse large puncta; AM at level of ALs; PLs off scutum (peniscutum); anterior scutal angles with ALs tend to reduce; $\mathrm{AM} \geq \mathrm{PL}>\mathrm{AL}$; all scutal setae with pointed apices and covered with long barbs; sensilla densely covered with scale-like barbs in proximal half, slightly expanded and covered with large spikes in distal half.

All legs 7-segmented, with 1 pair of claws and claw-like empodium. Leg I: coxa with 1 non-specialised branched seta (1B); trochanter 1B; basifemur 1B; telofemur 5B; genu 4B, 3 genualae, microgenuala; tibia 8B, 2 tibialae, microtibiala; tarsus $22 \mathrm{~B}$, tarsala $20 \mu \mathrm{m}$ long, microtarsala distal to tarsala, subterminala, parasubterminala, pretarsala. Leg II: coxa 1B; trochanter 1B; basifemur 2B; telofemur 4B; genu $3 \mathrm{~B}$, genuala; tibia $6 \mathrm{~B}, 2$ tibialae; tarsus $16 \mathrm{~B}$, tarsala $24 \mu \mathrm{m}$ long, microtarsala proximal to tarsala, pretarsala. Leg III: coxa $1 \mathrm{~B}$; trochanter $1 \mathrm{~B}$; basifemur $2 \mathrm{~B}$; telofemur $3 \mathrm{~B}$; genu $3 \mathrm{~B}$, very long genuala; tibia $6 \mathrm{~B}$, very long tibiala; tarsus $16 \mathrm{~B}$.

\section{Hosts}

Rhinolophus clivosus acrotis Heuglin (type host), Rhinolophus ferrumequinum (Schreber) (Chiroptera: Rhinolophidae), Miniopterus schreibersii (Kuhl) (Chiroptera: Miniopteridae). Here T. knighti is for the first time recorded on Plecotus austriacus (Chiroptera: Vespertilionidae). The most frequently used roosts by this bat in Spain (Ibáñez 1998) are crevices in caves, mines, tunnels, lofts and abandoned houses, and it can be found in agricultural areas and areas without trees.

Distribution: Yemen, Bulgaria (for S. balcanica). Here this species is recorded for the first time in Spain (Balearic Islands).

Type material examined: Paratype larva (ZIN) from Rhinolophus clivosus acrotis, Yemen, Ta'izz (Taiz), 1951, H. Hoogstraal; two paratypes larvae from NHM (Nos. NHM 1952.7.23.9 and BMNH(E) 1996.259) with same data.

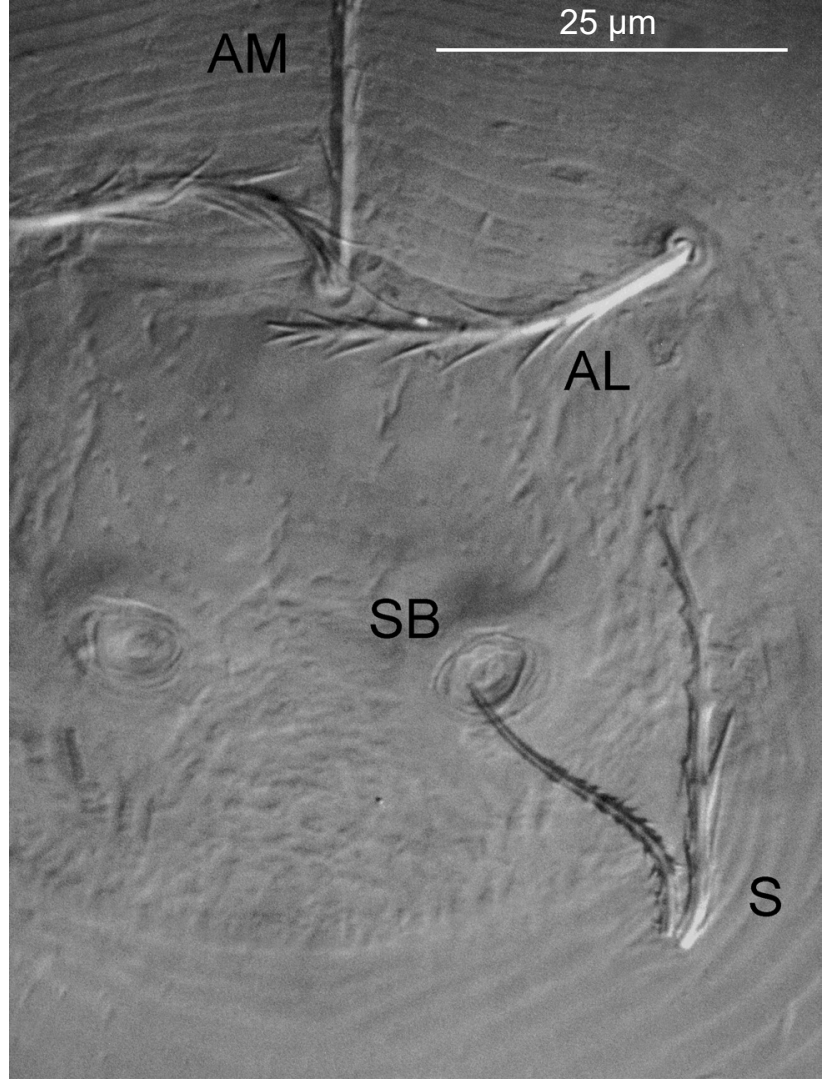

Fig. 7. Trisetica knighti (Radford, 1954), larval specimen ZIN 11171: scutum (one sensillum intact). Scale bar $25 \mu \mathrm{m}$. Abbreviations: $\mathrm{AL}$ - anterolateral scutal seta; $\mathrm{AM}$ - anteromedian scutal seta; $\mathrm{S}$ - sensillum; $\mathrm{SB}$ - sensillary base.

Additional material examined: Six larvae (ZIN 11167-11172) from P. austriacus (specimen 041121-3), Spain, Formentera, La Mola, 21 November 2004, collected by J. Quetglas.

Remarks: The combination Sasatrombicula (Rudnicula) knighti should be regarded as unpublished, since the checklist prepared by Vercammen-Grandjean (1965) contains a statement that it is not to be regarded as a publication (ICZN Code, 4th ed., Article 8.2). Although Kolebinova (1966) compared S. balcanica with T. knighti, she did not use that combination.

According to our examination of paratypes, those specimens have two pairs of eyes (not one pair as mentioned in the original description), as well as the specimens from Spain, although the posterior pair could be poorly visible.

As evident from the figure in the original description, sensilla of $T$. knighti are not flagelliform, contrary to the statement of Radford (1954): they are clearly expanded. This conclusion is also supported by the result of our examination of the paratype (NHM 1952.7.23.9).

Specimens from Spain differ from the type series in longer legs $(\mathrm{Ip}=918-952 \mu \mathrm{m} v s .817-851 \mu \mathrm{m}$ and TaIIIL $=90-95 \mu \mathrm{m} v s .81-83 \mu \mathrm{m})$; we estimate this difference as an evident case of geographic variability, on the basis of our results obtained for intraspecific variance in other species of chiggers (Daniel et al. 2010, Stekolnikov and Klimov 2010). 
A
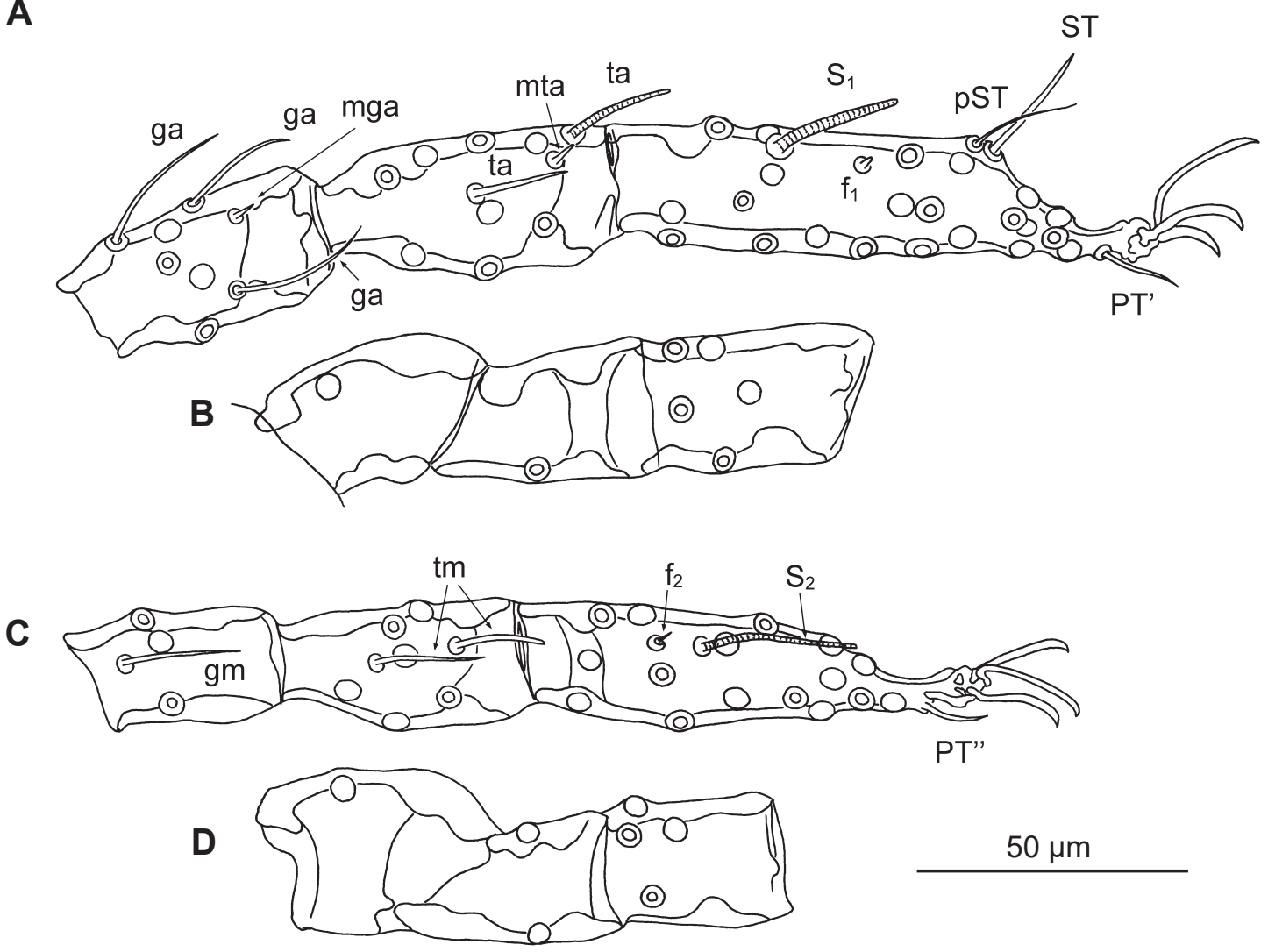

$50 \mu \mathrm{m}$

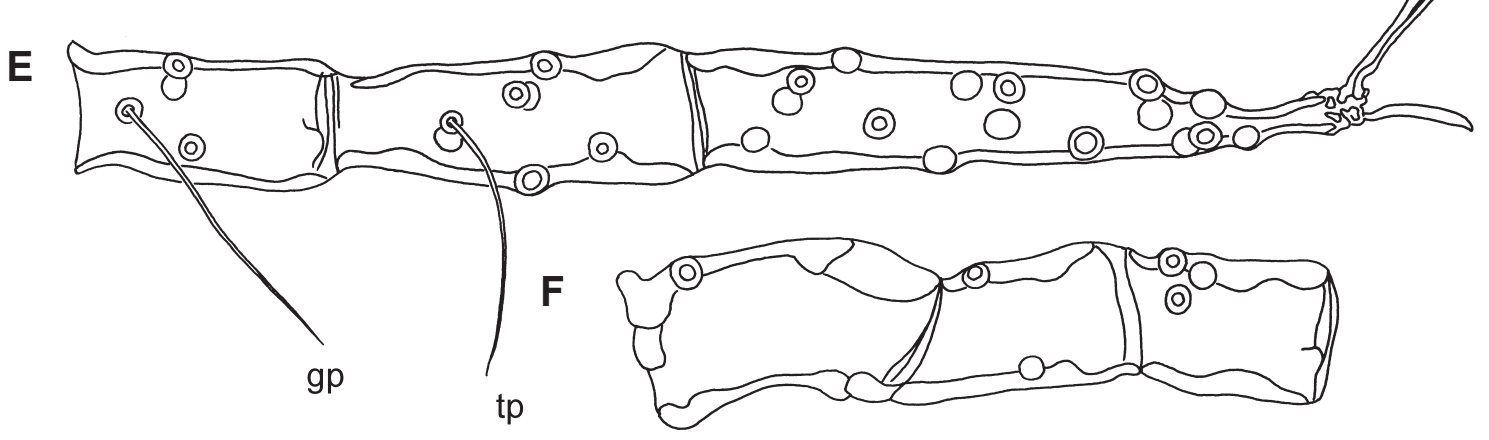

Fig. 8. Trisetica knighti (Radford, 1954), larva. A - genu, tibia, and tarsus of leg I in specimen ZIN 11168; B - trochanter, basifemur, and telofemur of leg I in specimen ZIN 11168; C - genu, tibia, and tarsus of leg II in specimen ZIN 11168; D - trochanter, basifemur, and telofemur of leg II in specimen ZIN 11168; E - genu, tibia, and tarsus of leg III in specimen ZIN 11169; F - trochanter, basifemur, and telofemur of leg III in specimen ZIN 11169. Abbreviations: $f_{1}$ - famulus I; $f_{2}$ - famulus II; ga - genuala I; gm - genuala II; gp genuala III; mga - microgenuala I; mta - microtibiala; ST - subterminala; pST - parasubterminala; PT' - pretarsala I; PT" - pretarsala II; $\mathrm{S}_{1}$ - tarsala I; $\mathrm{S}_{2}$ - tarsala II; ta - tibiala I; tm - tibiala II; tp - tibiala III.

In the description of S. balcanica the following differences of this species from T. knighti were given: 1) fPp $=\mathrm{B} / \mathrm{B} / \mathrm{BNB} v s . \mathrm{B} / \mathrm{B} / \mathrm{NNB} ; 2)$ DS 50 , VS 50 , and NDV 100 vs. 66,54 , and 120 , respectively; 3 ) standard measurements (without specification) (Kolebinova 1966). According to the results of our examination, a paratype of $T$. knighti from ZIN has NDV 109 and NDV is 102-109 in the material from Spain (Table 1).

The original description of S. balcanica was based on a single specimen. Measurements of the holotype plus additional material from Bulgaria (Kolebinova 1992) do not significantly differ from those of $T$. knighti (Table 1). Thus, the only remaining difference between $S$. balcanica and $T$. knighti is $\mathrm{fPp}$; i.e. the dorsal palpal tibial seta is branched in the former species and nude in the latter. We suppose that a single character cannot justify separation of species; even more so because in the later description of S. balcanica Kolebinova (1992) explicitly stated that both dorsal and lateral palpal tibial setae are nude in this species. Probably, that trait is subject to variation. Therefore, we regard here S. balcanica as a synonym of T. knighti. 


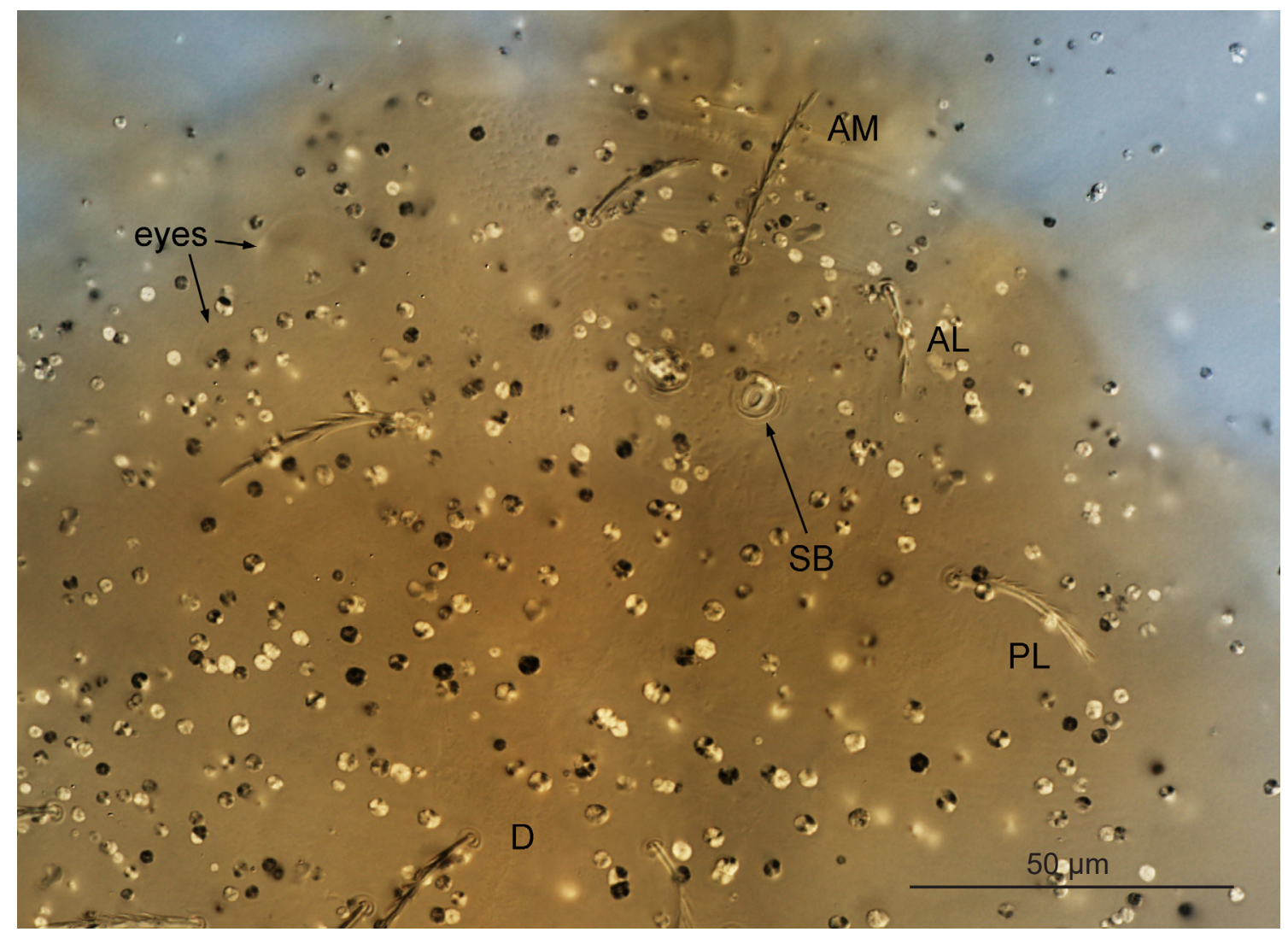

Fig. 9. Trisetica aethiopica (Hirst, 1926), larva-lectotype: scutum and dorsal idiosomal setae. Abbreviations: D - dorsal idiosomal setae; AL - anterolateral scutal seta; AM - anteromedian scutal seta; PL - posterolateral scutal seta; SB - sensillary base.
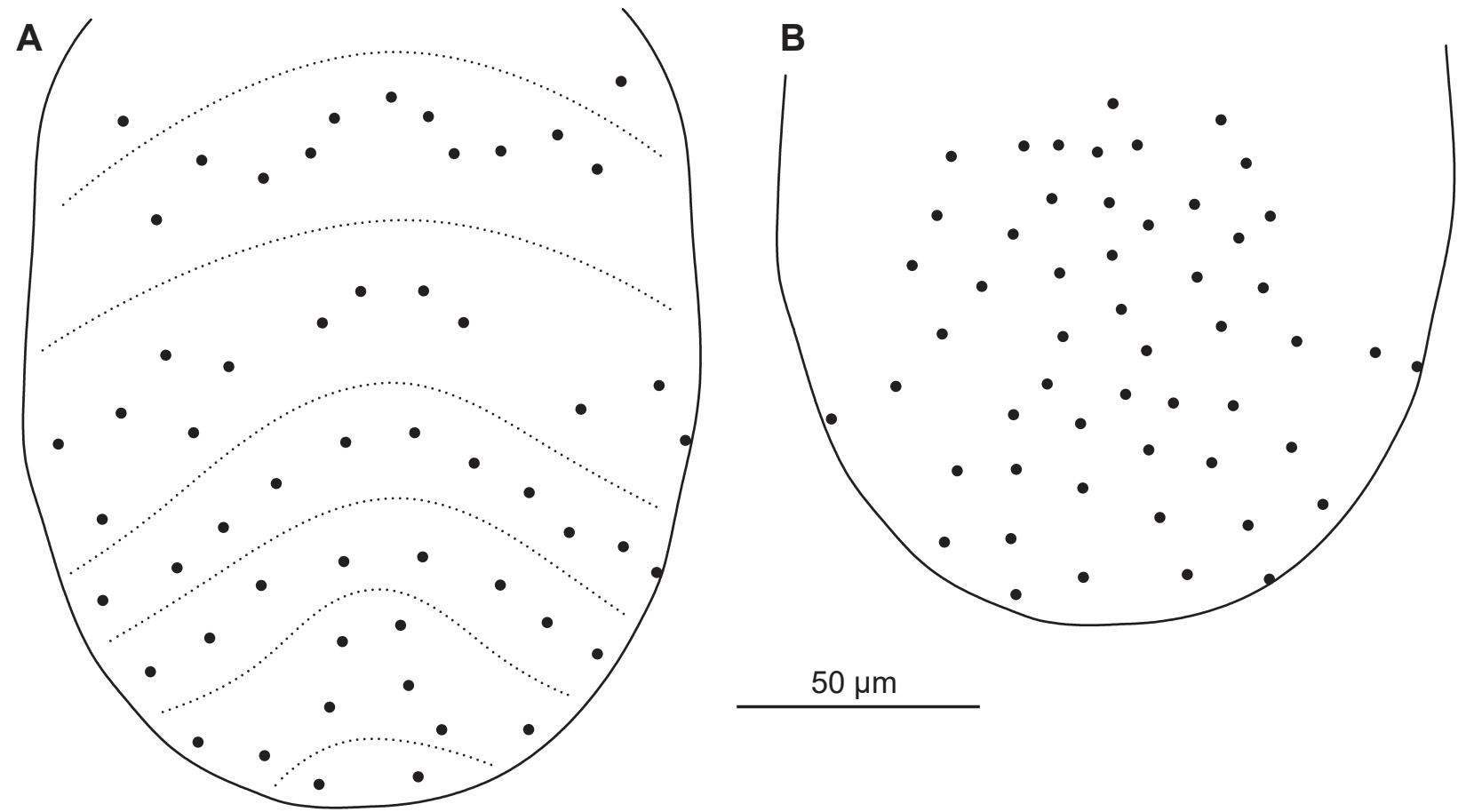

Fig 10. Trisetica aethiopica (Hirst, 1926), larva-lectotype. A - arrangement of dorsal idiosomal setae; B - arrangement of ventral idiosomal setae (excretory pore is invisible). 


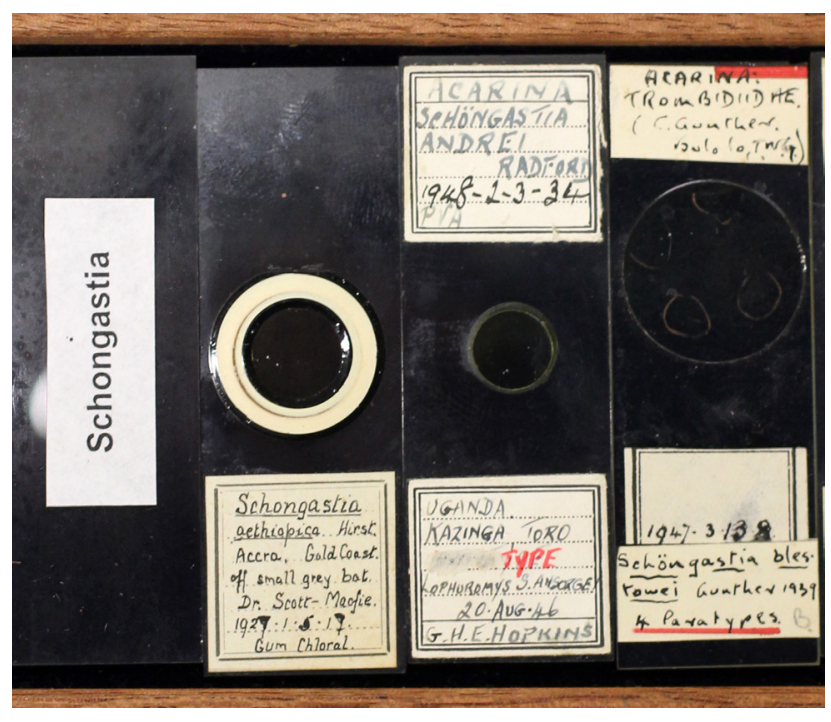

Fig. 11. A fragment of NHM collection containing the lectotype of Trisetica aethiopica (Hirst, 1926) (left slide; photographed by Alexandr A. Stekolnikov).

Trisetica knighti is similar to T. aethiopica (Hirst, 1926) in the presence of four setae on the palpal tarsus and three genualae I and differs from it in the presence of sensilla slightly expanded in the dorsal half vs. fusiform (Hirst 1926), a larger scutum $(\mathrm{SB}=21-25 \mu \mathrm{m} v \mathrm{~s} .14 \mu \mathrm{m}, \mathrm{ASB}=$ 32-35 $\mu \mathrm{m}$ vs. $24 \mu \mathrm{m}$ ), longer setae (e.g. AM = 38-51 $\mu \mathrm{m}$ vs. $30 \mu \mathrm{m}, \mathrm{AL}=31-40 \mu \mathrm{m} v s .19 \mu \mathrm{m}, \mathrm{PL}=46-52 \mu \mathrm{m} v s$. $33 \mu \mathrm{m})$, and in longer legs $(\mathrm{Ip}=817-952 \mu \mathrm{m} v s .720 \mu \mathrm{m}$, TaIIIL $=81-95 \mu \mathrm{m} v s .66 \mu \mathrm{m})$.

Trisetica knighti is similar to T. melvini Traub et Evans, 1950 in the shape of sensilla (covered by scale-like barbs proximally, slightly expanded and bearing large spikes distally) but clearly differs from it in the presence of four branched setae on the palpal tarsus vs. five, three genualae I vs. two, and in the presence of two posterior sternal setae vs. six (Traub and Evans 1950).

\section{Trisetica aethiopica (Hirst, 1926)}

Figs 9, 10

Schöngastia aethiopica - Hirst (1926): 827, fig. 2.

Schöngastia aethiopica - Radford (1942): 68, fig. 60; (1952): 103; André (1946): 54, figs 1-3; Thor and Willmann (1947): 305, fig. 363.

Ascoschöngastia aethiopica - Wharton and Fuller (1952): 71; Taufflieb (1960): 224

Ascoschöngastia (Ascoschöngastia) aethiopica - Zumpt (1961): 160, fig. 93a.

Trisetica aethiopica - Vercammen-Grandjean (1965): 132; (1967): 849; Stekolnikov (2018): 116.

Diagnos is: $\operatorname{SIF}=4 \mathrm{~B}-\mathrm{N}-3-3111.0000 ;$ fsp $=7.7 .7 ; \mathrm{fCx}=$ 1.1.1; $\mathrm{fSt}=2.2 ; \mathrm{fPp}=\mathrm{B} / \mathrm{B} / \mathrm{NNB} ; \mathrm{fSc}: \mathrm{PL}>\mathrm{AM}>\mathrm{AL} ; \mathrm{Ip}=$ $720 ; \mathrm{fD}=2 \mathrm{H}-11-13-11-8-2-6-2 ; \mathrm{DS}=55 ; \mathrm{VS}=53 ; \mathrm{NDV}=$ 108; sensilla fusiform. Standard measurements (in $\mu \mathrm{m}$ ) and counts of lectotype: AW 47, SB 14, ASB 24, AM 30, AL 19, PL 33, H 26, $D_{\text {min }} 17, D_{\text {max }} 27$, pa 270, pm 194, pp 256, Ip 720,
DS 55, VS 53, NDV 108, TaIIIL 66, TaIIIW 17. The diagnosis is based on our examination of the lectotype (measurements, counts, arrangement of dorsal and ventral idiosomal setae) and literature data (shape of sensilla, chaetotaxy of legs and gnathosoma). The lectotype is in poor condition; the slide includes multiple extraneous inclusions (Fig. 9) and main diagnostic traits of the species are difficult to distinguish.

Type material examined: Syntype larva (NHM 1927.1.5.17), which is designated here as lectotype: Accra, Gold Coast, off small grey bat, collector Scott-Macfie, gum chloral.

Distribution and hosts: This species was described from an unidentified bat in Ghana. Later it was also recorded on Myotis goudoti (Smith) in Madagascar and on Rhinolophus hildebrandtii Peters in South Sudan. On one occasion, it was also found on the eyelid of a human baby in Uganda (Radford 1952, Stekolnikov 2018).

Lectotype designation: The original description of T. aethiopica does not include any information on the number and deposition of the type specimens (however, the word "specimens" used by the author implies that there was more than one specimen). Among the authors who cited that species name, only Wharton and Fuller (1952) stated that its type material was deposited in the British Museum (at present, NHM). This statement can be supported by the fact that Hirst (1926) was the collection curator at NHM when he published the description of T. aethiopica (The National Archives 2019).

However, according to the results of our revision of the NHM collection, it contains a single specimen labeled as Schongastia (sic) aethiopica, without any inscription defining its type status, but with the collection data coinciding with those given in the original description (Fig. 11). Since this specimen lacks the sensilla, although they were figured in the original description, we conclude that other type specimens could exist at least at the time of original desciption. Therefore, we designate this specimen (NHM 1927.1.5.17) as the lectotype of Schöngastia aethiopica.

Oudemansidium komareki (Daniel et Dusbábek, 1959)

Trombicula (Leptotrombidium) komareki - Daniel and Dusbábek (1959): 421, figs 1-5.

Leptotrombidium komareki - Kepka (1964): 568, fig. 4.

Myotrombicula komareki - Schluger and Vshivkov (1967): 912, figs 9-16.

Oudemansidium komareki - Schluger and Vysotzkaja (1970): 165; Kudryashova (1998): 139, fig. 99.

Chiroptella (Oudemansidium) komareki - VercammenGrandjean and Langston (1976): 904, pl. 261.

Leptotrombidium (Leptotrombidium) fasciatum - Feider (1968): 409, figs 1-4.

Type deposition: Holotype 585/1 in the Institute of Parasitology, Biology Centre of the Czech Academy of Sciences, České Budějovice, Czech Republic.

D istribution: Austria, Bulgaria, Romania, Slovakia, Moldova, Crimea, and Azerbaijan. Here this species is recorded for the first time in Spain.

Hosts: Eptesicus serotinus (Schreber), Myotis daubentonii 
(Kuhl), Myotis myotis (Borkhausen), Plecotus auritus (Linnaeus), P. austriacus, Pipistrellus pipistrellus (Chiroptera: Vespertilionidae), R. ferrumequinum, Rhinolophus hipposideros (Bechstein) (Chiroptera: Rhinolophidae), Arvicola terrestris (Linnaeus) (Rodentia: Cricetidae). Here this species is recorded for the first time from Pipistrellus kuhlii. In Spain this host species roosts in crevices of buildings, rocks and trees, as well as tree hollows and bat-boxes (Ibañez 1998).

Material examined: Seven specimens (ZIN 11160 11166) ex one Pipistrellus kuhlii (samples 180112-3 and 180112-6), Spain, Menorca, Alaior, bat-box 9, 12 January 2018, collector J. Quetglas.

\section{DISCUSSION}

The genus Trisetica is similar to two bat-parasitising genera, Trombigastia Vercammen-Grandjean et Brennan, 1957 and Perissopalla Brennan et White, 1960. Some species of Trombigastia have a peniscutum (i.e. the insertion of posterolateral setae off the scutum), like Trisetica, and both Trombigastia and Perissopalla are characterised by the shape of sensilla, similar to that of Trisetica melvini and T. knighti - with only a slightly expanded distal part. This trait is reminiscent of Sasatrombicula Vercammen-Grandjean, 1960, Rudnicula Vercammen-Grandjean, 1964, and Grandjeana Koçak et Kemal, 2009; genera of bat chiggers belonging to the tribe Trombiculini, which differ from the Schoengastiini, including Trisetica, Trombigastia, and Perissopalla, by the presence of flagelliform sensilla $v s$. expanded (from fusiform to globose). Note that species of Grandjeana sometimes have a peniscutum (Kalúz and Ševčík 2015). Therefore, all of the above genera represent cases in which the border between Trombiculini and Schoengastiini becomes unclear. Another similar case is the relationship between Ascoschoengastia Ewing, 1946 and Microtrombicula Ewing, 1950, which are identical in all traits, except the shape of sensilla (from slightly expanded to clavate in Ascoschoengastia versus flagelliform in $\mathrm{Mi}$ crotrombicula) (Domrow and Lester 1985).

\section{REFERENCES}

Trisetica knighti and T. aethiopica have the same number of palpal tarsal setae (4) as Rudnicula (T. melvini has five palpal tarsal setae, like species of Perissopalla, Sasatrombicula, and Grandjeana; Trombigastia has seven setae); in addition, $R$. dimolinae (Audy, 1952) and $R$. leytensis (Brown, Goff et Nadchatram, 1988) possess slightly expanded sensilla, and $R$. becki Nadchatram, 1968 has posterolateral scutal setae situated on projections of the scutum (Nadchatram 1968), which can be regarded as an intermediate stage between the normal scutum and peniscutum. Thus, an integration of Rudnicula and Trisetica could be subject to discussion, after a thorough examination of all species included in both genera. In addition, Vercammen-Grandjean (1965) moved Trombicula (Anomalaspis) rhinopomae Vercammen-Grandjean, 1963 to the genus Rudnicula, although this combination is unavailable due to the status of the cited work (see above). Therefore, this species, which has a peniscutum, slightly expanded sensilla and five palpal tarsal setae, should also be considered among the above-mentioned taxa.

Acknowledgements. We are grateful to Jan Beccaloni, curator of the collection of Arachnida, and to Hannah Armer, the light microscopy imaging suite manager (NHM), for their valuable assistance during the visit of A. Stekolnikov to the Museum. We appreciate the courtesy of prof. Milan Daniel (National Institute of Public Health, Prague, Czech Republic) who donated a series of voucher specimens, including a paratype of Trombicula knighti, to ZIN. The first author appreciates his wife, Victoria A. Stekolnikova (ZIN), for her help in slide preparation. We thank Benjamin L. Makepeace (Institute of Infection \& Global Health, University of Liverpool, Liverpool, UK) for linguistic corrections and two anonymous reviewers for useful comments. The visit of A. Stekolnikov to NHM was performed under the remit of the project on the fauna and taxonomy of African chiggers supported by the Russian Foundation for Basic Research, grant No. 16-0400145-a. Sampling expeditions by J. Quetglas were supported by the Balearic Environment Administration, contract 2221/2004 "Status, distribution and conservation measures of Chiroptera in Formentera", and a research grant by the Menorcan Studies Institute. Bats were handled under authorisation CEP 11-17 of the Balearic Environment Administration.
André M. 1946: Sur le genre Schöngastia Oudemans 1910 et la présence à Madagascar du Sch. aethiopica Hirst (Acariens, Thromb.). Bull. Mus. Natl. Hist. Nat. Paris, 2e sér. 18: 53-55.

Brown W.A., Goff M.L., Nadchatram M. 1988: The bat-infesting genus Rudnicula (Acari: Trombiculidae), with description of a new species from the Philippine Islands and a key to the species. J. Med. Entomol. 25: 17-19.

Daniel M., Dusbábek F. 1959: Trombicula (Leptotrombidium) komareki $\mathrm{n}$. sp., un nouveau parasite des chiroptères en Tchécoslovaque. Acarologia 1: 421-425.

Daniel M., Stekolnikov A.A., Hakimitabar M., Saboori A. 2010: Chigger mites (Acari, Trombiculidae) parasitizing small mammals in the Eastern Hindu Kush and some other Afghan areas. Parasitol. Res. 107: 1221-1233.

Domrow R., Lester L.N. 1985: Chiggers of Australia (Acari: Trombiculidae): an annotated checklist, keys and bibliography. Aust. J. Zool. Suppl. Ser. 114: 1-111.
Feider Z. 1968: Nouvelles larves de Trombiculides (Acariformes) parasites sur les mammifères de la Roumanie. Zool. Anz. 180: 409-423.

Fernandes S.J. S., Kulkarni S.M. 2003: Studies on the trombiculid mite fauna of India. Rec. Zool. Surv. India, Occ. Paper 212: $1-539$.

Goff M.L. 1989: Catalog of types in the National Chigger Collection of the U.S. National Museum of Natural History, Smithsonian Institution (Acari: Trombiculidae). Bull. Soc. Vector Ecol. 14: 95-134.

Hirst S. 1926: Description of new mites, including four new species of "red spider". Proc. Zool. Soc. London 96: 825-841.

IвÁÑez C. 1998: Order Chiroptera. In: J.C. Blanco (Ed.), Spanish Mammals. GeoPlaneta, Barcelona, pp. 114-221.

Kalúz S., Ševčík M. 2015: A new species of Grandjeana (Acari: Trombiculidae) from heart-nosed bat (Chiroptera: Megadermatidae) in Ethiopia (Africa) with notes to biogeography of this genus. Biologia 70: 380-385. 
KePKa O. 1964: Die Trombiculinae (Acari, Trombiculidae) in Österreich. Z. Parasitenkd. 23: 548-642.

Kolebinova M. 1966: [A contribution to the studies on the larvae of subfamily Trombiculinae (Acarina, Trombiculidae) parasitic on birds and mammals in Bulgaria.] Bull. Inst. Zool. Mus. Sofia 22: 71-80. (In Bulgarian.)

Kolebinova M. 1992: [Acariformes, Trombidioidea, Trombiculidae, Leeuwenhoekiidae.] Aedibus Academie Scientiarium Bulgaricae, Sofia, 172 pp. (In Bulgarian.)

Kudryashova N.I. 1998: [Chigger Mites (Acariformes, Trombiculidae) of East Palaearctics.] KMK Scientific Press, Moscow, 342 pp. (In Russian.)

Nadchatram M. 1968: Notes on the genus Rudnicula (Acarina, Trombiculidae) with description of a new species from Malaysia. Acarologia 10: 467-471.

RADFORD C.D. 1942: The larval Trombiculinae (Acarina: Trombidiidae) with descriptions of twelve new species. Parasitology 34: $55-81$.

RADFORD C.D. 1952: Larval trombiculid mite as human parasite at Mulago, Kampala, Uganda. Trans. Roy. Soc. Trop. Med. Hyg. 46: 103.

RADFORD C.D. 1954: Some mites of Yemen collected by the Medical Mission of the United States Naval Medical Research Unit No. 3. Fieldiana 34: 295-313.

Schluger E.G., Vshivkov F.N. 1967: [Trombiculid mites (Acariformes, Trombiculidae) from the Crimea.] Entomol. Obozr. 46: 909-915. (In Russian.)

SChluger E.G., VysotzKaJA S.O. 1970: [On the fauna of chigger mites (Acariformes, Trombiculidae) from the Transcarpathian Region.] Parazitologiya 4: 153-165. (In Russian.)

Stekolnikov A.A. 2018: Taxonomy and distribution of African chiggers (Acariformes, Trombiculidae). Eur. J. Taxon. 395: $1-233$.

Stekolnikov A.A., Klimov P.B. 2010: A revision of chiggers of the minuta species-group (Acari: Trombiculidae: Neotrombicula Hirst, 1925) using multivariate morphometrics. Syst. Parasitol. 77: 55-69.

Stekolnikov A.A., Santibáñez P., Palomar A.M., Oteo J.A. 2014: Neotrombicula inopinata (Acari: Trombiculidae) - a possi- ble causative agent of trombiculiasis in Europe. Parasit. Vectors 7: 90

Stekolnikov A.A., WaAp H., Gomes J., Antunes T. 2016: Chigger mites of the genus Ericotrombidium (Acariformes: Trombiculidae) attacking pets in Europe. Vet. Parasitol. 221: 60-63.

Taufflieb R. 1960: Étude d'une collection de Trombiculidae d'Afrique Occidentale. Acarologia 2: 224-237.

The National Archives 2019: British Museum (Natural History): Department of Zoology: Arachnida Section: Correspondence. World Wide Web electronic publication, https://discovery. nationalarchives.gov.uk/details/r/C16009, 04/2019.

Thor S., Willmann C. 1947: Acarina: Trombidiidae. In: F.E. Schulze, W. Kükenthal and K. Heider (Eds.), Das Tierreich 71b. Walter de Gruyter, Berlin, pp. 187-541.

Traub R., Evans T.M. 1950: A new genus and species of trombiculid mite from Burma (Acarina). J. Parasitol. 36: 341-394.

Vercammen-Grandjean P.H. 1965: Trombiculinae of the World. Synopsis with Generic, Subgeneric, and Group Diagnoses (Acarina, Trombiculidae). George Williams Hooper Foundation, San Francisco, $191 \mathrm{pp}$.

Vercammen-Grandjean P.H. 1967: Revision of the genus Tecomatlana Hoffmann, 1947 (Acarina: Trombiculidae). Acarologia 9: 848-864.

Vercammen-Grandjean P.H. 1968: The Chigger Mites of the Far East (Acarina: Trombiculidae \& Leeuwenhoekiidae). U.S. Army Medical Research and Development Command, Washington, D.C., $135 \mathrm{pp}$.

Vercammen-Grandjean P.H., Langston R.L. 1976: The Chigger Mites of the World (Acarina: Trombiculidae et Leeuwenhoekiidae). Vol. III. Leptotrombidium complex. George Williams Hooper Foundation, University of California, San Francisco, $1061 \mathrm{pp}$.

Vercammen-Grandjean P.H., Nadchatram M. 1963: Le genre Trombicula et ses sous-genres (Trombiculidae-Acarina). Acarologia 5: 384-393.

Wharton G.W., Fuller H.S. 1952: A manual of the chiggers. Mem. Entomol. Soc. Washington 4: 1-185.

Zumpt F. (ED.) 1961: The arthropod parasites of vertebrates in Africa south of the Sahara (Ethiopian Region). Vol. 1: Chelicerata. Pub. South Afr. Inst. Med. Res. 11: 1-457.

Cite this article as: Stekolnikov A.A. and Quetglas J. 2019: Bat-infesting chiggers (Acariformes: Trombiculidae) of the Balearic Islands and new data on the genus Trisetica Traub et Evans, 1950 Folia Parasitol. 66: 017. 